\title{
FACTORS AFFECTING EXPANDED
} \section{ELECTRICITY TRADE IN NORTH AMERICA}

\author{
Lawrence J. Hill \\ Energy Division
}

Date Published: January 1994

\author{
Prepared for \\ Office of Policy, Planning, and Program Evaluation \\ U.S. DEPARTMENT OF ENERGY \\ OAK RIDGE NATIONAL LABORATORY \\ Oak Ridge, Tennessee 37831 \\ Managed by \\ MARTIN MARIETTA ENERGY SYSTEMS, INC. \\ for the \\ U.S. DEPARTMENT OF ENERGY \\ under Contract No. DE-AC05-84OR21400
}

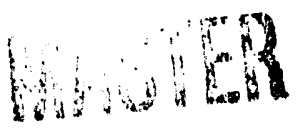


LIST OF FIGURES AND TABLES $\ldots \ldots \ldots \ldots \ldots \ldots \ldots \ldots \ldots$

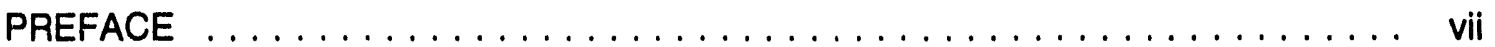

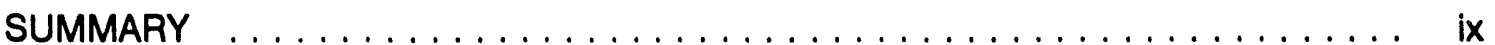

1. PURPOSE AND SCOPE OF THE STUDY $\ldots \ldots \ldots \ldots \ldots \ldots \ldots \ldots \ldots$

2. AN OVERVIEW OF EXISTING ELECTRICITY TRADE IN NORTH AMERICA $\ldots \quad 3$

2.1. Regulation of Electricity Trade in North America . . . . . . . . . . . 3

2.2. Trade Flows over the Past Decade .................... 3

3. BENEFITS OF INTERNATIONAL ELECTRICITY TRADE $\ldots \ldots \ldots \ldots \ldots \ldots$

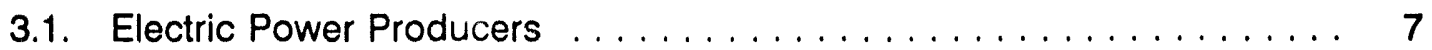

3.2. Electric Power Consumers $\ldots \ldots \ldots \ldots \ldots \ldots \ldots$

4. NAFTA AS A FACILITATOR OF EXPANDED ELECTRICITY TRADE $\ldots \ldots \ldots \ldots 11$

4.1. Provisions of NAFTA Related to Electricity Trade . . . . . . . . . . 11

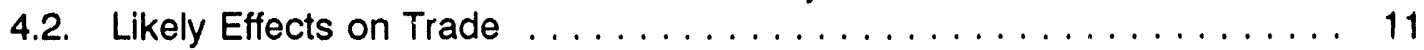

5. THE TRADE SETTING: THE ORGANIZATION OF ELECTRIC POWER INDUSTRIES IN NORTH AMERICA $\ldots \ldots \ldots \ldots \ldots \ldots \ldots \ldots$

6. FACTORS AFFECTING ELECTRICITY TRADE $\ldots \ldots \ldots \ldots \ldots \ldots \ldots$

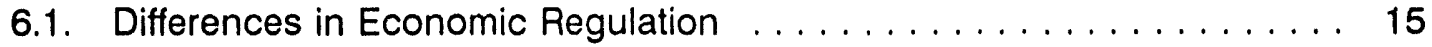

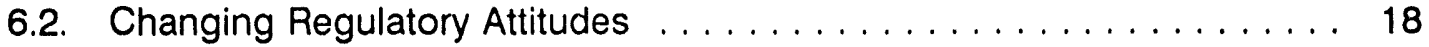

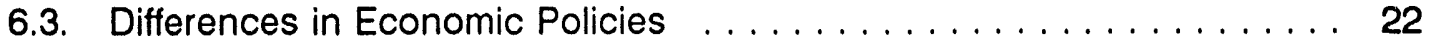

6.4. Differences in Environmental Policies . . . . . . . . . . . . . . . 23

6.5. The Changing Structure of Electric Power industries in North America . . . . . . . . . . . . . . . . . . . . . . . 24

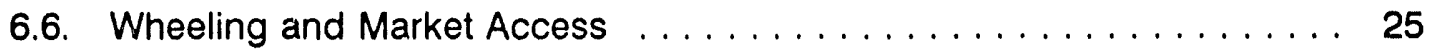

7. CONCLUSION $\ldots \ldots \ldots \ldots \ldots \ldots \ldots \ldots \ldots \ldots \ldots \ldots \ldots \ldots$

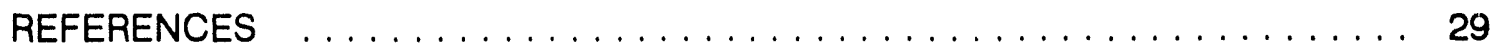




\section{LIST OF FIGURES}

Figure

Description

Page

$1 \quad$ Electric Transmission Capacity in North America

4

LIST OF TABLES

\begin{tabular}{lll}
\hline Table & Description & Page
\end{tabular}

1 U.S. Electricity Trade with Canada and Mexico,

Selected Years, $1981-1991 \ldots \ldots \ldots \ldots \ldots \ldots \ldots$

2 Estimated Energy and Peak Load Savings from DSM Programs,

U.S. Electric Utilities, 1990 and 2000 . . . . . . . . . . . . . . . . . 19

$3 \quad$ Estimated Energy and Capacity Savings from DSM

Programs, Canadian Provinces, 2000 and $2010 \ldots \ldots$ 


\section{PREFACE}

This report was prepared by Oak Ridge National Laboratory (ORNL) for the Office of Policy, Planning, and Program Evaluation (PO-51). The report reflects the views of the author and does not necessarily reflect the views or official position of the U.S. Department of Energy or the Office of Policy, Planning, and Program Evaluation. However, Russell Profozich, Kathy Deutsch, and Hank Santiago of that office provided very helpful comments. Also, Doug Bauer, the manager of the Energy Division's (ORNL) office in Washington, D.C., provided helpful comments on earlier versions of the study. 


\section{SUMMARY}

Decisions on cross-border electricity trade between enterprises in Canada, the United States, and Mexico are based largely on financial considerations. For electricityimporting enterprises, the key consideration is whether the benefits of electricity imports (i.e., the avoided capacity and operating costs) exceed the costs of importing electricity, including the costs of transmitting it over national borders. Similarly for exporting utilities, the key consideration is whether the profits obtained from exporting electricity are more or less than those obtainable from selling the power internally.

These incentives for cross-border trade arise, of course, because of differences in the cost of providing electricity by enterprises in the three countries. Differences in costs are due to (1) natural and cyclical factors and (2) differences in economic institutions and policies in the three countries.

Differences in costs due to natural and cyclical factors that tend to promote crossborder trade are well-known. For example, differences in the types of fuels available in the three countries affect generating mix and cost and can affect trade. Similarly, trade is promoted to the extent that an enterprise in one country can produce electricity more cheaply than an enterprise in another, given the same generating mix. Cyclical fluctuations frequently promote trade. For example, variations in annual rainfall alter the attractiveness of trade for hydro-dominant utilities. Differences in daily or seasonal peak loads between utilities also could stimulate trade. Finally, changes in the business cycle promote trade as excess-capacity utilities evolve into deficit utilities as regional economic activity increases. The opposite is true when regional economic activity declines.

Underlying institutional and policy differences that affect the relative costs of producing electricity by different enterprises in different countries and may affect trade are less well-known. These differences are the subject of this study. We divide them into three broad categories.

The first is related to differences in the economic regulation of electric power industries in the three countries, including different cost-recovery practices and changing attitudes about demand-side management.

Second, differences in national and subnational policies related to energy, the environment, and the economy can affect the relative costs of producing electricity in the three countries and make electricity trade more or less attractive. For example, differences in energy taxation in the three countries change the relative cost of fuels for electricity generation. Policies toward capital access and capital cost influence production costs. A stringent environmental policy related to fossil fuels in one country can impede trade.

Finally, the structure of electric power sectors can also influence cross-border trade. An important consideration here is the rapidly changing U.S. power sector that may lead decisionmakers to be more conservative in making investment decisions. 


\section{PURPOSE AND SCOPE OF THE STUDY}

In this study, we explore factors that affect electricity trade between enterprises in the United States and Canada and the United States and Mexico. We look beyond obvious factors tending to promote trade--e.g., different electric generating mixes; cyclical changes in weather and economic activity--to those underlying policy and institutional factors that affect the relative costs of producing electricity in the three countries. In particular, we consider six such factors that appear to have a significant impact on electricity trade in North America:

- Differences in the types of economic regulation of power in the three countries, leading to differences in cost recovery for wholesale and retail power and wheeling charges.

- Changing regulatory attitudes in the three countries, placing more emphasis on demand-side management and environmental concerns over burning fossil fuels in electricity generation.

- Differences in energy and economic policies in the three countries that directly affect the relative cost of producing electricity and the price of traded electricity.

- Differences in national and subnational environmental policies in the three countries that influence decisions on the location of power plants.

- Changing organization of electric power industries in the three countries which may foster uncertainty, change historical relationships among utilities in individual countries and among utilities across borders, and provide other potentially important sources of power for distribution utilities.

- Differences in the ability of enterprises in the three countries to gain access to electric power markets because of restrictions placed on transmission access.

We take a qualitative approach, examining differences in these six factors to see how--and in what direction--they influence incentives to trade. A rigorous cost-benefit analysis is not conducted for any utility in the sense that the benefits of expanded trade (i.e., the avoided capacity and fuel costs) are quantified and compared with the transmission capacity costs and purchased power costs. Nor is a benefit-cost study of expanded trade undertaken for individual countries in the sense that the employment and income benefits are quantified and compared with the costs of engaging in electricity trade.

It is important to point out that we do not consider physical impediments to trade, especially the existing lack of transmission capacity between electric power markets in the three countries. We assume that if a capacity deficit exists, it is a short-run, financial consideration: if the financial rewards of trade are sufficiently large, the transmission lines will be constructed over the longer term. 
Also, we do not consider factors that are the basis for trade. Therefore, we do not discuss differences in generating mix among the three countries as an explanatory reason for trade. In the same vein, we do not consider cyclical fluctuations. A good example is cyclical weather patterns affecting hydroelectric production. Another example is fluctuations in the business cycle of the three countries resulting in fluctuating income and electric generating capacity levels.

A recent policy initiative by governments of the three countries to promote trade is not the primary focus of the study. However, we summarize provisions of the Free Trade Agreement (FTA) between Canada and the United States and the North American Free Trade Agreement (NAFTA) among Canada, the United States, and Mexico dealing with electric power and their potential effect on future electricity trade in North America.

The next four sections set the stage for discussion of policies and institutional arrangements presented in Section 6. In Section 2, we discuss the regulation of electricity trade in North America by the three governments and provide an overview of the recent trading experience for electricity between Canada and tha United States and between Mexico and the United States, including the volume of that trade over the past decade and existing transmission capacity between regions of the three countries. In Section 3, we look at the benefits that accrue to trading countries and, based on recent studies, what those benefits are likely to be for the three countries. The discussion in Section 4 centers on the relevant provisions of the United States-Canada Free Trade Agreement and the proposed North American Free Trade Agreement among Canada, the United States, and Mexico.

In Section 5, we set the stage for the discussion of policy and institutional differences presented in Section 6 by outlining differences in the organization of the electric power sectors of Canada, the United States, and Mexico. The study is synthesized in Section 7. 


\section{AN OVERVIEW OF EXISTING ELECTRICTTY TRADE IN NORTH AMERICA}

\subsection{REGULATION OF ELECTRICITY TRADE IN NORTH AMERICA}

Canada, the United States, and Mexico regulate electricity exports at the national level. However, only Mexico regulates electricity imports.

Federal regulation of U.S. electricity exports is nominal. The Department of Energy issues 'presidential permits' for construction of international transmission lines and authorizes electricity exports. The Secretary of Energy has the authority to issue the permit after environmental review under the National Environmental Policy Act. At the state level, proposed transmission facilities must undergo prudence reviews by state regulatory commissions. Those reviews typically consider the economics of the facility, the impact on tariffs, and environmental impacts.

In Canada, the National Energy Board issues export licenses and certifies international transmission facilities for Canadian utilities. Public hearings are required if a transmission link will economically harm another province, harm the environment, or if other Canadian purchasers desire access to the power.

In Mexico, the Ministry of Energy, Mines, and State Industry, the Ministry of Programming and Budgeting, and the Ministry of Commerce and Industrial Promotion have review authority over electricity imports and exports.

The ultimate decision to pursue expansion of electricity trade between the United States and Canada and the United States and Mexico rests with individual utilities and other wholesale providers. That decision, of course, is based on the financial attractiveness of the potential trade and must conform with trade regulations and policies of the respective countries.

\subsection{TRADE FLOWS OVER THE PAST DECADE}

At any point in time, the amount of electricity trade in North America depends on the relative costs of electricity generation among trading partners and the physical interconnections between the three countries. Existing interconnections are shown in Figure 1. The Northeastern portion of the United States has the highest degree of interconnection with Canada. New England has 10 major interconnections and New York has 11 interconnections with Ontario and Quebec. Texas has six interconnections with Mexico and California has four. As shown in Figure 1, electricity trade between Mexico and the United States is limited. The reason is that, with the exception of the CaliforniaBaja region, the electrical systems of the two countries are not synchronous. The transmission capability between Texas and Mexico is normally disconnected and can be used only on a "block-loading" basis where physical portions of one system are separated and then loaded onto another.

In Table 1, we present the amount of U.S. exports and imports of electricity to and from Canada and Mexico for the period 1981 through 1991. Imports from Canada declined dramatically from 1987, dropping 60 percent from 50 terawatt-hours (tWh) in 
Figure 1

Electric Transmission Capacity in North America

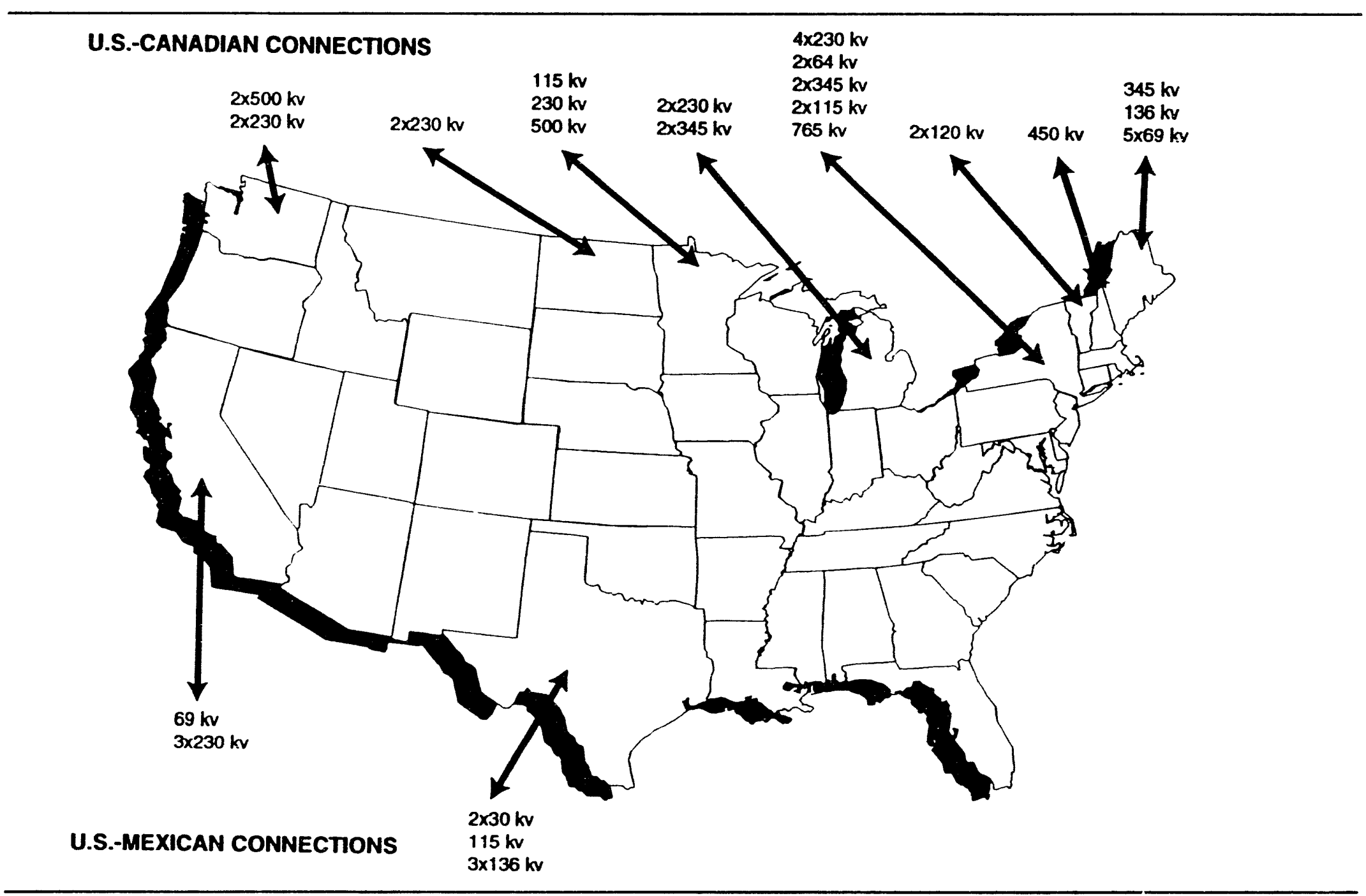

SOURCE: U.S. Department of Energy, Energy Information Administration (1993). 
1987 to $20 \mathrm{tWh}$ in 1990. The reason for the drop in imports was higher growth of demand in Quebec combined with a drought, reducing Quebec's excess hydro availability. Also, Ontario Hydro's Darlington nuclear units were delayed and some of its coal-based generation was restricted because of environmental requirements to limit sulphur dioxide $\left(\mathrm{SO}_{2}\right)$ emissions (U.S. Department of Energy, Energy Information Administration, 1992). U.S. exports to Canada increased for corresponding reasons.

Table 1

U.S. Electricity Trade

with Canada and Mexico

Selected Yzars

1981-1991

(In tWh)

\begin{tabular}{lrrrrr}
\hline & \multicolumn{2}{c}{ Canada } & & \multicolumn{2}{c}{ Mexico } \\
\cline { 2 - 3 } Year & Exports & Imports & Exports & Imports \\
& & & & \\
\hline & 2.5 & 35.5 & 0.3 & - \\
1981 & 4.7 & 39.2 & 0.1 & 1.5 \\
1986 & 5.8 & 50.2 & 0.1 & 2.0 \\
1987 & 6.9 & 36.8 & 0.2 & 2.0 \\
1988 & 14.5 & 24.2 & 0.6 & 1.9 \\
1989 & 19.9 & 20.6 & 0.6 & 2.0 \\
1990 & 7.9 & 28.7 & 0.6 & 2.1 \\
1991 & & & & \\
\hline
\end{tabular}

SOURCE: U.S. Department of Energy, Energy Information Administration (1993).

Amounts reflect all electricity trade between the United States and Canada and the United States and Mexico, including trade based on (1) firm power contracts, (2) non-firm (interruptible) power contracts, and (3) power exchanges.

A '-' denotes statistical insignificance. 


\section{BENEFITS OF INTERNATIONAL ELECTRICITY TRADE}

The benefits accruing to nations from trade are well known. Expanded consumption possibilities result as nations are no longer limited to consuming just what they produce. Stated alternatively, nations experience an increase in real income due to increased buying power. Trade provides an opportunity for redirection of resources to firms that export goods abroad. This redirection provides an opportunity for firms to expand production and possibly make advances in production techniques and technologies which further lower the costs of production and stimulate more trade.

In this section, we narrow this broader focus, addressing benefits that accrue to electric power producers and their customers as a result of international electricity trade. Many of the benefits can be identified easily, while others need to be explained in more detail. To facilitate presentation, the discussion is organized first around benefits accruing to electric power producers and, then, their customers. For each, the discussion is further divided between benefits to importers and exporters, and shared benefits.

\subsection{ELECTRIC POWER PRODUCERS}

A primary benefit of trade for electric utilities importing firm power is that they can avoid constructing generating capacity. By not making this investment, the utility is able to keep its rate base down, and therefore keep its costs down. Further, importing firm power may allow the utility to take advantage of scale economies in the future when it has to replace existing capacity. That is, by importing firm power in the present instead of building new capacity, the utility may be able to construct a larger plant in the future that will replace the imported power and service higher levels of electricity demand more economically.

Similar benefits exist for imporiing interruptible power to satisfy peak loads. Because of the relatively high operating wosts of generating electricity for peak loads, the purchase of interruptible power can save substantial amounts of money expended for fuel. That is, in most cases, the power being imported will be provided by base-load capacity in the exporting country with a relatively low fuel cost. Even if the exporter charges a price greater than its own marginal cost of power production, the power may be substantially less expensive than the marginal cost of power produced by the importing utility.

If the exporting utility has excess base-load capacity, the firm power that it sells to other utilities can increase the amount that the exporter produces, and thereby allow it to take advantage of scale economies. A benefit of selling interruptible power is that the exporter may be able to use base-load capacity for peak demand. That is, instead of using a plant with high operating costs to meet peak demand, a plant with lower operating costs can be used. If the power is needed to meet the exporter's peak demand, the exported power can be interrupted and used for its own customers.

Benefits can also be shared by trading partners as both national and international nnvironmental regulations become more market-based. Power trades will begin to occur not only between low- and high-cost producers, but also between low- and high-cost 
emitters. A utility generating electricity from coal, for example, may import power produced by relatively higher-cost plants if it helps to meet environmental requirements. This may reduce environmental damage internationally. Depending on the nature of the regulatory mechanism (e.g., incentive-based mechanisms such as emissions trading), this can bring further financial gains (e.g., sales of emissions permits between the trading partners or some other third party).

\subsection{ELECTRIC POWER CONSUMERS}

From the consumer's perspective, the most important benefit is the lower cost of production--and hence lower price--of electricity. The benefits can be realized both at present through decreases in the price of electricity and in the future by avoiding price increases. In some cases, the consumption of imported power will reduce the purchasing utility's overall cost and thus reduce the price the consumer pays. In other cases, the imported power avoids cost to the utility that would be passed on to the customer in terms of higher prices. A price decrease or an avoided price increase depends on the nature of the contract.

If the utility imports interruptible power to reduce operating costs, the customer may realize a price decrease. That is, because the importing utility is receiving electric power for less than it can produce it, its costs are lower, and it may pass this savings on to the customer. The amount of cost savings depends on the terms of the contract.

If the utility imports firm power, it may avoid producing some base-load power. In most cases, the utility delays investment in new plant and equipment, avoiding a large capital, rate-base expenditure that would be recovered from its customers. By importing power instead of building new plants, the utility only has to recover the price of the imported power, and not the construction and equipment cost.

These savings can be substantial. In a study conducted by the John F. Kennedy School of Government at Harvard, for example, Lee, Foster, and Parson (1988) estimated conservatively that U.S. electric power customers--primarily in the Northeast and Midwest-saved $\$ 283$ million by importing cheaper Canadian electricity in 1986 . Of the total, $\$ 105$ million was saved from interruptible contracts and $\$ 178$ million from firm power sales. The estimates were based on a comparison of the contract pricing policies of Canadian firms and the avoided costs of U.S. electric utilities.

In a more recent study, the National Energy Board of Canada (1992) estimated that nearly $8,000 \mathrm{MW}$ of capacity additioris could be avoided--saving $\$ 25$ billion--through increased trade between Canadian and U.S. utilities. To obtain these estimates, the NEB identified five geographical regions for which opportunities for increased trade appeared to be practical. Within each region, they estimated the levelized unit energy cost of new generation and associated transmission facilities and annual capacity requirements. These data were used to identify opportunities for trade between utilities in Canadian provinces and between utilities in Canadian provinces and the United States beginning in the year 2000 . Finally, the $8,000 \mathrm{MW}$ and $\$ 25$ billion are only indicative of the savings in resulting from enhanced trade between Canada and the United States. 
The main benefit received by customers of the utility exporting power is a cost reduction. As explained above, the utility that exports power oftentimes has excess capacity. By exporting power, the utility is able to spread fixed costs over a larger sales volume, reducing the average cost of power to its customers.

As with the production side of the discussion in Section 3.1, a shared benefit between importers and exporters is a potential decrease in environmental degradation. If firms are trading power to reduce emissions, customers benefit from an improved environment--or at least one that is not degraded as much. If a customer utility finds it eas $^{\prime}$, to buy power produced in another region in order to meet local environmental standards, the local customers of the importing utility will benefit from the reduction in emissions. Customers in the region where the power is produced also will benefit if the utility can utilize state-of-the-art control technology financed in part from revenue derived from electricity imports. The customers of both the trading utilities and even third parties will be better off with the improvement in the regional environment. It is this win-win aspect of electricity trade that has aroused the interest of environmentalists. 


\section{NAFTA AS A FACILTTATOR OF EXPANDED ELECTRICTTY TRADE}

\subsection{PROVISIONS OF NAFTA RELATED TO ELECTRICITY TRADE}

Canada, the United States, and Mexico recognize the importance of liberalized energy trade in the North American Free Trade Agreement (N,FTA). For electricity, two provisions are important.

First, in Annex 602.3 the Agreement recognizes Mexico's commitment to maintain ownership of natural resources, including production, transmission, and distribution of electricity by the Comision Federal de Electricidad (CFE):

In Mexico, the supply of electricity as a public service is a strategic area reserved to the state.

However, the Agreement goes on to define three opportunities for private investment in Mexico's electric generating facilities: (1) investment in electricity production for a facility's own use in which entities can generate electricity to meet their own supply needs; (2) cogeneration, in which entities can use the heat or steam from an industrial process to generate electricity; and (3) independent power production, in which firms in Canada and the United States may own and operate power plants for the sale of electricity to CFE or for the export of such power. The likely impact of each of these three provisions on expanded electricity trade between the United States and Mexico will be discussed below in Section 6.

Second, the language of the Agreement reconfirms the commitment of the United States and Canada to terms of the Free Trade Agreement that was signed by the two countries in the 1980s:

Canada and the United States shall act in accordance with the terms of Annexes 902.5 and 905.2 of the Canada-United States Free Trade Agreement.

\subsection{LIKELY EFFECTS ON TRADE}

The most important effects of NAFTA on electricity trade are likely to be indirect. These indirect effects will likely arise from two sources.

First, NAFTA is likely to result in a rate of economic growth in the three countries higher than would be possible in absence of the agreement. To the extent that these higher economic growth rates materialize, higher electricity growth rates also may materialize. This is especially true for Mexico as higher per-capita income leads to the penetration of more electricity-using goods (e.g., air conditioners). And, to the extent that economic developmert and growth is near border regions (i.e., Canada-United States, Mexico-United States:, the more likely that electricity trade will be financially attractive to utilities and other enterprises along the border. 
Second, the provisions of NAFTA provide for natural gas exports from the United States to Mexico. Although U.S. firms cannot own Mexican natural gas-producing facilities, Mexican entities such as state-owned enterprises, end users, and suppliers will be able to negotiate natural gas supply contracts with U.S. firms. These gas contracts together with the reduction in tariffs on energy-producing equipment (e.g., combustion turbines) that are part of NAFTA's provisions and are to take place in the first few years of the treaty should make gas-fired electric generating units more appealing to Mexico than they historically have been. Also, natural gas is a more environmentally appealing alternative to other fossil fuel-fired generating sources such as coal and oil. Thus, in addition to the opportunity for expanded bilateral trade in natural gas, there also may be opportunities for increased electricity trade between the United States and Mexico. These opportunities, of course, will depend upon the extent to which electricity produced from combustion turbines in Mexico can compete with other sources of supply by U.S. electric utilities and be exported to U.S. enterprises. 


\section{THE TRADE SETTING: \\ THE ORGANIZATION OF ELECTRIC POWER INDUSTRIES \\ IN NORTH AMERICA}

Electricity trade does not occur between countries. Electricity trade occurs between enterprises in countries--primarily between electric utilities. Therefore, decisions on importing and exporting electricity depend on ownership of the enterprises. To appreciate the complexity of utility decisionmaking on acquiring electric resources in the three countries--including imported electricity as one of the potential resources--one must understand differences in the ownership and organizational structures of the electric power industries in the three countries.

One big difference is size. The U.S. electric power industry is much larger than that of Canada's or Mexico's. In 1991, total electric generating capacity in the U.S. electric power industry was 738.3 gigawatts (GW), not including $50 \mathrm{GW}$ of non-utility generation. Canada has a little over $100 \mathrm{GW}$ of total capacity, while Mexico has approximately one-fourth of Canada's total.

Another big difference is the degree of centralization of electric power decisionmaking in the three countries. The organizations of the electric power sectors in the United States, Canada, and Mexico vary radically, with decisionmaking ranging from the highly centralized in Mexico to the highly decentralized in the United States. Decisionmaking in Canada falls in between that of Mexico and the United States.

The United States has one of the most decentralized and diverse electric power sectors in the world. It has more than 3,000 electric utilities either (i) privately owned with shares traded on stock exchanges, (ii) publicly owned by the federal government (Tennessee Valley Authority, five federal power marketing agencies), (iii) publicly owned by subnational governments (i.e., state, county, or city-owned), or (iv) owned by cooperatives in rural areas. In terms of capacity, sales, and revenues, privately owned utilities dominate the U.S. industry. In 1991, they owned 77 percent of the electric generating capacity, accounted for 77 percent of the sales, and generated 79 percent of the revenues in the U.S. electric utility industry.

Although federal power projects account for only 9 percent of the total electric generating capacity, they are among the largest electric power enterprises in the economy. The Tennessee Valley Authority, a corporation owned by the Federal government, is the largest U.S. electric utility with $30.7 \mathrm{GW}$ of capacity in five states, accounting for more than four percent of total U.S. generating capacity. The U.S. Army Corps of Engineers is the fifth largest U.S. electric enterprise with $20.0 \mathrm{GW}$ (2.7 percent of the U.S. total) of capacity in 18 states. This is significant for electricity trade because of differences in cost and ratemaking procedures for Federal utilities (to be discussed below) and because much of the Corps' capacity is in states that are near or directly border Canada (e.g., Washington and Oregon in the Northwest). The New York Power Authority, a state-owned enterprise bordering Canada, is also one of the largest U.S. electric enterprises with nearly $7 \mathrm{GW}$ of total generating capacity, has different ratemaking procedures than other U.S. utilities, and also borders Canada. 
The organization and regulation of the Mexican power sector contrasts sharply with that of the L'nited States. After nationalization of the Mexican electric power sector in the early 1960s, CFE evolved into the state integrated power monopoly. Under Mexican constitutional law, CFE is the sole owner, generator, transmitter, and distributor of power in the country. Its Governing Board determines its annual budgets and investment plans, and authorizes tariff changes. The Board consists of government ministers, the operating director of CFE, and three trade union representatives.

The organization of Canada's electric power sector falls between the extremes of Mexico and the United States. There is central direction, but it is organized along provincial lines. Under the Canadian constitution, provinces own their own natural resources. Although Canada's electric power sector is composed of (1) Crown-owned corporations, (2) investor-owned utilities, and (3) municipally owned utilities, the bulk of generation, transmission, and distribution is provided by three Crown-owned utilities: Ontario Hydro, Hydro-Quebec, and British Columbia Hydro and Power Authority. Together, these three utilities account for approximately four-fifths of the Canadian power industry. Regulatory authority over production, transmission, and distribution of eleciricity rests with the 10 provinces. 


\section{FACTORS AFFECTING ELECTRICTTY TRADE}

The motivation for cross-border electricity trade in North America is rooted in differences in the costs of producing electricity by enterprises in the three countries. Given the same institutional arrangements and policies toward energy, the economy, and the environment in the three economies, natural and cyclical factors would determine these cost differences. That is, factors such as (1) differences in the types and costs of energy resources in the three countries, (2) annual rainfall for hydroelectric facilities, and (3) regional economic growth rates would largely determine trade patterns in North America.

However, national and subnational policies and institutional arrangements are not the same in the three countries. Differences in these policies and arrangements can affect the financial attractiveness of trade that would otherwise occur on the basis of natural and cyclical factors. In the remainder of this section, we explore seven such differences in institutional arrangements and policies that could affect electricity trade between enterprises in North America.

\subsection{DIFFERENCES IN ECONOMIC REGULATION}

Differences in the economic regulation of electric power production, transmission, and distribution in the three countries reflects differences in the organization of the power sectors in the three countries. Differences in regulatory mechanisms can have a significant effect on the regulated price of electricity charged by electric enterprises and, therefore, the financial attractiveness of trade. Two regulatory phenomena are important. The first is related to overall energy and capital costs. That is, do electricity rates reflect the total cost of producing electricity? The second phenomenon is related to capital costs. How are capital costs recovered in the electricity rates of electric enterprises in the three countries?

The answers to these questions for U.S. electric utilities are complicated because regulatory institutions are lodged at federal, state, and local levels for investor-owned, publicly owned, and cooperative utilities. The following paragraphs on the federal, state, and local regulation of the three ownership types provide a flavor for the complexity of the U.S. regulatory structure.

Regulation and ratemaking for U.S. electric utilities are the most complex and diverse, reflecting the size and diversity of ownership of U.S. electric utilities. Economic regulation rests at multiple levels and is different for different ownership categories of eleciric utilities. For example, economic regulation of investor-owned utilities is generally based on the rate base. That is, electric utilities are allowed to recoup operating and fuel expenses, plus a fair return on invested capital. On the other hand, the concept of rate base is not generally used in regulation of publicly owned electric utilities. Target interest coverage ratios generally apply for these utilities. Clearly, this can make a difference in the prices charged by U.S. electric utilities. And, to the the extent that different types of U.S. utilities are located on Canadian and Mexican borders, regulatory differences can influence electricity trade. 
At the federal level in the United States, the three primary regulatory functions of the Federal Energy Regulatory Commission (FERC) can influence the financial attractiveness of electricity trade with Canadian and Mexican enterprises: (1) economic regulation of wholesale electricity rates, including sales to full requirements and partial requirements utilities and coordination transactions among utilities; (2) regulation of electric power wheeling, which has taken on increased significance with enactment of the Energy Policy Act of 1992; and (3) licensing of private sector hydroelectric projects.

Subnational regulation of U.S. electric utilities depends on ownership type. Economic regulation of electricity sales to end-users by investor-owned utilities is generally under the jurisdiction of state regulatory commissions. The exceptions are the states of Tennessee and Nebraska in which virtually all sales are made by publicly owned or cooperative utilities. For investor-owned utilities, there are two primary aspects of rate-of-return regulation. First, an $10 \mathrm{U}$ determines and a state commission approves the level of revenues required to maintain its financial viability. From an accounting and financial standpoint, this activity includes determining the cost of providing electricity and a rate of return that is (1) sufficient to compensate contributors of capital (owners and creditors) for their investment and (2) large enough to attract new capital. The second aspect of economic regulation involves determining the structure of rates charged to individual customer classes--given the overall level of allowed revenues.

In contrast to regulation of investor-owned utilities, few state-level regulatory bodies have jurisdiction over the rate level and rate structure of state/municipal electric systems. Approximately one-half of municipal utilities are under the direct control of the governing municipal legislative body, while the other half are under the jurisdiction of an independent power board. For those municipals under the jurisdiction of an independent board, one quarter are controlled by elected boards and the remainder are controlled by boards that are appointed by either the mayor, the city's governing board, or by the mayor with approval of the city governing board.

This variety of the political and economic climates in which municipals operate makes generalizations about their pricing incentives difficult. In contrast to ratemaking for investor-owned utilities, state and municipal systems do not, in general, price electricity to recoup a fair or equitable return on rate base plus other operating expenses. However, they do share one common constraint: the requirement to generate a net margin (net income) sufficient to attract external funding at a reasonable rate. In terms of pricing incentives, the pricing strategy is to set rate levels in order to generate revenues sufficient to cover all operating costs (including the cost of debt) plus a net margin large enough to generate a sufficiently large interest coverage ratio. A rule-of-thumb ratio is 2.0 . The ratemaking scheme of state/municipal systems begins at the "bottom line" (net income) which is used to determine the required revenues or rate level of the utility.

Regulatory authority over pricing by rural electric cooperatives is lodged at three different levels. The Rural Electrification Administration (REA) has overall responsibility to ensure the financial soundness of the cooperatives. At the state level, 20 state regulatory commissions have economic jurisdiction over cooperatives. For those cooperatives not under state regulatory jurisdiction, regulation is implemented on the basis of REA policy with respect to financial soundness. The rule-of-thumb or policy that 
has evolved for rural electric cooperatives is that, for distribution borrowers, the times-interest-earned ratio should exceed 1.5 and, for power supply borrowers, the corresponding ratio should be at least 1.0 .

Federal power operations are divided into two segments: (1) five Power Marketing Agencies (PMAs), including Bonneville Power Administration (BPA) in the Northwest and (2) the Tennessee Valley Authority (TVA). TVA is a government corporation and relatively more autonomous than the PMAs with respect to rate determination. Its rate level and rate structure are set internally, outside the purview of Federal and state regulatory bodies. The rate structures and rate levels of the five PMAs, however, are reviewed and approved by the Federal Energy Regulatory Commission.

Regulation of PMAs is especially important for electricity trade between the United States and Canada because of BPA's importance to the transmission of electricity in the Northwest. Rates in PMAs are determined through a complicated process involving a yearly federal investment repayment study. Briefly, PMAs are required to set rates to cover operation and maintenance expenses (including depreciation), the cost of purchased power, and debt service. The priority of payment of expenses is in the same order. The annual rate studies determine potential adjustments to the rate level. Future O\&M expenses and purchased power costs are estimated for a five-year period and then are assumed to remain constant after this period for 45 years. For debt service coverage, a constant repayment schedule is computed for each project so that all of the Federal government's investment in generation facilities is paid back within 50 years and, for the investment in transmission facilities, within 35 to 45 years.

TVA's overall ratemaking guideline is to maintain rates as low as possible consistent with satisfying three tests to ensure financial stability. The pricing structure of TVA is not intended to earn a specific return on invested capital in its electric system (retained earnings and the investment of the federal government). Therefore, TVA's pricing process is similar to the rate-setting process of municipally owned systems that do not necessarily price to maximize profit subject to a return on invested capital.

In contrast to this diversity in the United States, the Mexican power sector is monopolized by CFE, a state-owned enterprise. Regulation, including approval of rates, is carried out by the Ministry of Energy, Mines, and State Industry. Also, the Ministry of Programming and Budgeting and the Ministry of Treasury and Finance approve the budgets. A Board of Governors, headed by the Secretary of Energy, Mines, and State Industry, consists of prominent members of the Ministries of Treasury, Agriculture, Water Resources, Commerce, and the Director of Petroleos Mexicanos, the state-owned oil and gas company. The ratemaking philosophy in Mexico is not to recoup a fair return on rate base similar to U.S. investor-owned utilities. Ratemaking philosophy leans more toward the approach of publicly owned utilities in the United States because of the covenants entered into with multilateral assistance banks in their power sector loans. Those covenants generally require that CFE achieve some target interest coverage ratio and percentage of capital funds generated internally by setting the overall level of prices sufficiently high. CFE's operating and capital budgets have been subsidized for a long time, with the average price lower than average cost of service. Foreign credits have also been used to finance generating projects. 
In Canada, individual provinces have primary responsibility for the generation, transmission, and distribution of electricity. Federal regulatory authority is limited to nuclear energy (by the Atomic Energy Control Board) and international and interprovincial trade. The National Energy Board advises the federal government on energy matters. For the electric power sector, its major responsibilities rest with licensing electricity exports and certifying cross-border transmission lines. Regulation in the provinces varies. Canada's utilities are allowed to recover costs in varying degrees depending in which provinces they are located.

\subsection{CHANGING REGULATORY ATTITUDES}

Over the past decade, U.S. regulatory commissions have increasingly required utilities under their jurisdiction to engage in integrated resource planning (IRP), a management model that explicitly considers electric utility demand-side resource options in the utility planning processes in addition to conventional supply resources. Under the IRP process, changing the pattern (load management) and level (energy conservation) of electricity demand--i.e., demand-side management (DSM)--is weighed as a resource option on an equal footing with traditional supply resources (e.g., building new generating stations, extending the life of old ones, or seeking purchased power sources). To the extent that the IRP process enables electric utilities bordering Canada and Mexico to shave system peaks and/or reduce capacity requirements, there may be less need for imported interruptible and firm power. Similar IRP processes are gaining increasing attention in Canada and Mexico.

For the United States, a recent survey of 24 utilities in 24 states showed the nature of the IRP process and the effect that it is having on the selection of resources (Hill, Hirst, and Schweitzer, 1991). Of the 24 states surveyed, legislation or administrative orders in 18 require utilities to prepare integrated resource plans. And, 11 of the commissions in the 18 states formally approve the plans. Finally, approval by the commission for use of a resource depends on its inclusion in a formal resource plan in seven of the states. Statistical analyses of the utilities' responses in the 24 states suggest that utilities required by legislation or administrative order to prepare long-term integrated resource plans rely more heavily on DSM to meet additional peak demand than those utilities not required to prepare a plan.

The amount of resources that U.S. utilities are expecting from DSM is not trivial. To get an idea of the magnitude of expected savings, in Table 2 we present some evidence on the projected contribution of DSM programs to meeting future electric energy $(\mathrm{kWh})$ and peak load $(\mathrm{kW})$ in the United States. The results are based on survey responses from 24 U.S. electric utilities in 1990. The 24 utilities represent one-third of the U.S. electric utility industry in terms of peak load. The survey results are presented on two bases: (1) the percentage of total resources (i.e., energy services supplied) accounted for by DSM programs, which can also be interpreted as the percentage reduction of total demand attributable to DSM programs; and (2) the percentage of incremental resources (i.e., energy services supplied) accounted for by DSM programs, which is the fraction of additional resources added by utilities in the 10-year period from 1990 to 2000 that are accounted for by DSM programs. 
Table 2

Estimated Energy and Peak Load Savings from DSM Programs

U.S. Electric Utilities

1990 and 2000

(In Percentages)

\begin{tabular}{lccccc}
\hline \multirow{2}{*}{ Type of Savings } & \multicolumn{2}{c}{ Energy $^{\mathbf{a}}$} & & \multicolumn{2}{c}{ Peak Load $^{\mathbf{a}}$} \\
\cline { 2 - 3 } & 1990 & 2000 & & 1990 & 2000 \\
\hline Total Resource Basis & 0.5 & 3.8 & & 1.3 & 6.2 \\
Incremental Resource Basis & NA & 15.5 & & NA & 27.7 \\
\hline
\end{tabular}

SOURCE: Schweitzer, Hirst, and Hill (1991).

aWeighted average, based on responses from 24 utilities. Peak could occur in the summer or winter depending on the demand characteristics of individual utilities.

NA - Not Applicable

The survey results shown in Table 2 indicate that U.S. utilities will significantly increase their DSM activities on a total resource basis from 1990 to 2000 . In the year 2000 , peak demand, for example, is forecast by these 24 utilities to be 6.2 percent less than it otherwise would be if DSM programs were not implemented. The savings on an incremental basis are much larger, of course. Nearly 30 percent of additional peak electric power resources $(\mathrm{kW})$ will come from the demand side in 2000 . Projected energy savings ( $\mathrm{kWh}$ ) are one-half of projected peak load savings, suggesting that load management programs (e.g., direct load control programs that change the time when e'ectricity is used) are more pervasive and/or effective than those aimed at improving energy efficiency (e.g., conservation programs).

The data in Table 2 are weighted averages of the 24 utilities responding to the survey. Clearly, individual utilities with varying operating conditions will have different potentials for DSM savings. For example, with all other conditions remaining the same, utilities that have aggressively pursued DSM programs in the past will not have the same savings potential ten years from now as those utilities just beginning DSM planning. Utilities with different climates and different load factors will also have different DSM potentials. Some of the utilities are projected to get as much as one-half of their additional energy and peak load resources from DSM resources in the the next ten years. Other utilities, however, will not obtain as much as five percent of their energy requirements from DSM programs. The variation across utilities is large. 
The more DSM resources are used, especially by utilities in states contiguous to Canada and Mexico, the more likely that opportunities for expanded electricity trade will be reduced. And, the evidence suggests that states bordering Canada are among the most aggressive in pursuing DSM: Washington and Oregon in the northwest, Wisconsin and Michigan in the midwest, and New York, Vermont, Maine, and Massachusetts in the northeast. The reason is that, not only does DSiv reduce the need for electric energy, it oftentimes changes the price of electricity and the availability of generating capacity for exports or the need for imports. Over the long run, implementing DSM programs is likely to reduce the need for trade.

Electric utilities in the Canadian provinces are also aggressively pursuing DSM programs. In Table 3, we summarize the expected savings from DSM programs for selected Canadian provinces ar,d in total for the years 2000 and 2010 . The three provinces with the largest trade balances with the United States--British Columbia, Ontario, and Quebec--are expected to get a significant amount of their resources from DSM in the next two decades.

Table 3

Estimated Energy and Capacity Savings from DSM Programs

Canadian Provinces

2000 and 2010

(In Percentages)

Province

Energy
2000 $\frac{2 \text { Capacity }}{2010} \quad \frac{2010}{2000}$

British Columbia

6.3

7.9

6.2

7.4

Ontario

6.4

10.6

10.8

19.2

Quebec

5.0

6.3

11.6

10.3

All Other

2.4

3.0

6.0

6.5

Total $^{\mathrm{a}}$

4.8

6.6

9.2

11.4

SOURCE: Calculated from Ministry of Energy, Mines, and Resources (1992)

aeighted average.

The data in Table 3 are on a total resource basis--i.e., percentage reduction in demand attributable to running DSM programs. Therefore, they correspond to the total resource basis data for U.S. electric utilities in Table 2. For the year 2000, the data show that Canadian utilities are projecting greater savings from their DSM programs than are 
the 24 U.S. electric utilities contained in the survey on both an energy and a capacity basis.

Finally, although currently not as far along as U.S. or Canadian utilities, the Mexican government and CFE have strong incentives to pursue IRP and to look to DSM as a source of economic resources for meeting higher expected levels of electric service needs in the future. Primary stimulus to increased interest in IRP is the expected high rate of growth in electricity demand and increased environmental awareness by Mexican policymakers.

Of the three North American countries, the Mexican economy is expected to grow the fastest. With economic development and growth comes the need for greater electric power services as the penetration of electricity-using goods increases along with increases in personal income. The electric power sector, however, is among the most capital-intensive sectors of an economy. Therefore, the opportunity cost of investing in electric power generating stations is high: a peso spent on electric power is not available for investment in infrastructure, industry, or other economic development needs. Therefore, a strong incentive exists to look to the demand side as a lower-cost alternative to satisfying electricity service needs than building new generating stations.

Mexico's recent experience with its nuclear power program is an example of the environmental and financial problems Mexican policymakers are likely to confront in building generating stations. Mexico currently has one, 675-MW nuclear reactor in operation, providing about three percent of its total electricity needs, and another reactor under construction that should be operational in 1994. Construction of these reactors at Laguna Verde began in 1975 and they were to be the cornerstone of a major Mexican nuclear power program consisting of 20 units by the year 2000. However, (1) public reaction to nuclear power in the aftermath of the Chernobyl accident and (2) financial problems delaying construction of the two units dampened policymakers' interest in nuclear power as a primary electric generating option.

Finally, legislation enacted recently in the United States will also spur increased electricity conservation. Improving the energy efficiency of the U.S. economy was one of the most widely supported elements of the Energy Policy Act of 1992. These provisions of the Act will likely increase the amount of future electricity services coming from the demand side.

The energy efficiency provisions of the Act are potentially far-reaching, addressing energy use in residential, commercial, and industrial buildings, putting into place programs to encourage energy efficiency, and building on existing programs that require specific levels of energy efficiency. The Act also mandates energy performance standards and labeling programs for products such as windows, commercial and industrial equipment, lamps, and plumbing products. The legislation also attempts to improve the efficiency of the nation's utilities by amending the Public Utility Regulatory Policies Act and requiring consideration of integrated resource planning by utilities and state regulatory commissions in determining cost-effective resources. The Act also exeripts from taxation all payments to residential customers and a percentage of payments to other classes of customers from utilities for the purpose of promoting conservation and 
efficiency investments. Over time, these changes are expected to defer or eliminate the need for significant amounts of new generating capacity.

\subsection{DIFFERENCES IN ECONOMIC POLICIES}

Differences in the fiscal, monetary, and industrial policies of the three North American countries can also have a significant influence on both the cost of inputs used to produce electricity and the imported price of electricity in the three couritries. Again, these differences in economic policies can affect the financial attractiveness of trade that would have occurred strictly on the basis of natural and cyclical phenomena.

Public policy toward the pricing of inputs used by electric utilities in generating electricity is an important factor in determining the relative cost of generating electricity across countries and, therefore, the incentives for imports and exports. The most important policy tools are imposing taxes on--or providing subsidies for--fuels or capital used for generating electricity. Clearly, the higher the subsidies provided to electric utilities for capital or fuels used in generating electricity, the more financially attractive the electricity from those utilities becomes. The reverse is true for energy taxes with no capital subsidies.

Fuel cost is an important factor in determining electricity prices, especially for low capital cost-high fuel cost options such as combustion turbines. In some countries, the cost of fuel for electricity generation is subsidized because of the belief that 'cheap' electricity is required for economic growth and development. In other countries, fuel inputs are taxed to discourage their consumption and to stop the foreign currency drain resulting from their import, thereby increasing the cost of electricity generated from these fuels. Current U.S. proposals to impose energy taxes would have this effect.

Another important cost of generating electricity is the cost of capital, especially for high capital cost-low fuel cost options such as hydroelectric facilities, nuclear power plants, and coal plants with advanced scrubbers. Here again, economic policies vary in different countries from capital subsidies for electricity generation to very high capital costs.

In the United States, the structure of capital costs for electric utilities varies, depending on their ownership type. Investor-owned electric utilities generally pay the going market rate for capital, but enjoy the benefits of investment tax credits, accelerated depreciation, and the like. The cost of capital for publicly owned utilities such as municipals, rural electric cooperatives, and federal power marketing agencies is subsidized to varying degrees. For example, municipal bonds are exempt from federal taxes, thereby lowering the cost of capital for municipally owned utilities. That makes high capital cost options relatively more attractive than if there were no subsidy.

To varying degrees, Canada also provides subsidies for capital used in electric power generation. For example, the provincial governments' guarantee of bond issues for financing electric facilities in Quebec can be viewed as a subsidy. The assets of CFE in Mexico are financed by funds provided by the national government. 
Similar arguments can be made for all other inputs used by utilities in addition to fuel and capital inputs. For example, differences in employee taxes for social security, medical care, and the like also influence the relative cost of providing electricity, but the impact on prices is less pronounced.

Another important element of cost related to trading electricity and a potentially important barrier to expanded trade is the cost of foreign exchange to purchase the electricity. Further, macroeconomic policies can influence exchange rates and thereby influence electricity trade. The effect of depreciating exchange rates on trade, of course, is unilateral--i.e., a depreciating currency makes imports more expensive for one trading partner, while it is a boon for the other.

\subsection{DIFFERENCES IN ENVIRONMENTAL POLICIES}

Environmental regulations in any of the three countries could affect the unit cost of electricity and, therefore, influence trade among the countries. In this regard, the most important regulations for electricity generation relate to air quality standards and power plant siting decisions. Obviously, the greater the degree to which effluents must be reduced and the greater the expenditures on optimal siting decisions, the higher the cost of electricity. For transmission lines, departures from optimal sites could also affect the unit cost of electricity.

For our purposes, the key points are not the appropriateness and effectiveness of an individual country's environmental policies in cost-effectively lowering emissions, but rather differences among the three countries in environmental regulations--and their enforcement--that could change the relative costs of electricity production and significantly influence trading patterns.

There appear to be major differences. A good example is the recently enacted Clean Air Act Amendments (CAAAs) in the United States. That act will likely increase the market for low-sulfur coal in the near to medium term before the penetration of new coal technologies. This will probably increase the cost of low-sulfur coal and decrease the cost of high-sulfur coal. If Mexican regulations permit the use of high-sulfur coal, the price differential between power produced in Mexico and that produced in the United States could increase, promoting the import of Mexican power.

Another example stems from the pollution permits allowed in the CAAA. This environmental benefit (the reduction of emissions that can lead to acid precipitation) can also be realized in monetary terms through the emissions trading program mandated in Title IV of the CAAA. In this case, by purchasing "clean" Canadian hydropower, New England utilities may avoid burning fuels that produce $\mathrm{SO}_{2}$. The permits that would otherwise be needed for these emissions can either be banked for future use, thereby reducing future environmental compliance costs, or sold outright to increase current revenue. 


\subsection{THE CHANGING STRUCTURE OF ELECTRIC POWER INDUSTRIES IN NORTH AMERICA}

The structure of the electric power sectors in the three countries are changing rapidly--especially in the United States. Change implies increased uncertainty over what is likely to happen in the future. Uncertainty in turn may cause electric utilities to be cautious about major new initiatives such as expanded international trade or construction of new transmission lines.

The industrial structure of the U.S. electric power sector is likely to change significantly over the next two decades. The change began with enactment of the Public Utilities Regulatory Policies Act in 1978 (PURPA) and was expedited with passage of the Energy Policy Act of 1992 (EPACT). These two pieces of legislation facilitate competition in the electric generating business, allowing business firms--including, subsidiaries of electric utilities--to build power stations outside of the traditional regulated environment and sell power to local distribution companies.

Under EPACT, the U.S. electric power industry may evolve from a group of vertically integrated, regulated monopolies--i.e., from production through transmission to distribution--to a competitive, wholesale power production industry with regulated transmission and distribution functions. (The latter two functions have natural monopoly characteristics and competition among suppliers would likely introduce uneconomic redundancy.) The goal of the legislation is to enable the most efficient 'business firms'-not necessarily electric utilities in the traditional sense--to produce electricity. Competition may evolve over time to displace regulation as the principal mechanism for allocating resources for power production. Existing utilities that are less efficient than their competitors may be relegated to acting as electricity brokers: purchasing power from independent generating companies and selling that power to ultimate users.

The relationship between FERC and state regulatory commissions is also likely to be affected by EPACT. Although the legislation opens up the wholesale generation industry to more competition, it also gives state and federal regulators more responsibility for ensuring that remaining monopoly power is checked. However, Congress did not define new boundaries for relationships between FERC and state commissions. Regulation may rely more on incentive mechanisms rather than on traditional cost-ofservice mechanisms.

Technological advances in long-distance transmission technology in conjunction with the provisions of EPACT could also foster major change in the industry. Allowing efficient independent power producers to gain access to a transmission grid with the prospect of very little line loss could lead to the location of generating stations far removed from final consumption centers.

The evolution of the industry has important ramifications for electricity trade both over th', short term as the industry evolves and over the longer term after the structural adjustments are completed. For the former, change implies uncertainty over what is likely to happen in the future. With uncertainty for electric utilities comes a disposition toward not making drastic changes--including construction of costly transmission lines. However, 
after the structural adjustments are completed, independent power producers may find an export niche in the Canadian or Mexivan markets and, with transmission access guaranteed over existing lines in the United States under EPACT--there could be greater exports of U.S. electricity to Mexico and Canada.

In Canada, recent reports by Canada's National Energy Board indicate that provincial government and utility interest in maintaining utility-owned generation and retaining local economic/employment benefits may have inhibited development of nonutility generation, transmission access, and pricing reforms, and interprovincial and international electricity trade. Lack of Canadian government authority to promote cooperation and trade by provincial utilities also was cited as a problem. Therefore, the Canadian industry is not likely to evolve in tandem with that of the United States.

In Mexico, the constitution provides for state ownership of the electric power sector for strategic reasons. However, the provisions of NAFTA will permit new private investment in electric generating facilities for a facility's own use, cogeneration, and independent power production. Therefore, on the surface, it appears that there is an opportunity for independent power producers to construct generating facilities in Mexico and export the power to the United States. A barrier to this may be CFE and transmission access, as discussed below.

\subsection{WHEELING AND MARKET ACCESS}

Clearly, electricity trade between enterprises in the three countries depends on the existence of markets and the ability of enterprises to to get electric power to those markets. For example, if a utility does not own transmission lines connecting the power systems of two countries and it wants to export power, its ability to do so depends on access to the transmission lines of other utilities.

Wheeling and market access issues have not arisen historically in Mexico because of CFE's monopoly. That is, CFE historically has controlled the grid from production through transmission to distribution. However, questions of market access could be prominent in the future. Under NAFTA, IPPs will be allowed to operate, but can these IPPS gain access to U.S. markets by using CFE's existing electricity transmission grid? Under NAFTA, an IPP would have to negotiate with CFE on terms of the transmission arrangement. Access is not guaranteed, but negotiated. That could be a barrier to expanded trade if negotiations are influenced by non-economic factors.

Transmission access should not be a barrier to trade from the United States to Canadian and Mexican enterprises. Under provisions of EPACT, assuming transmission capacity is available, transmission access to the existing network can be obtained by any wholesale supplier or purchaser or transmitting utility, if necessary by petitioning FERC. This access is decided by FERC on a case-by-case basis. If new capacity is required, the costs are to be borne by the applicant.

In Canada, British Columbia Hydro and Trans-Alta (Alberta) Utilities have currently developed transmission access policies designed to promote interprovincial and international electricity trade. There is no national policy or requirement that other utilities 
in Canada's provinces provide wheeling services, except on a voluntary basis. This lack of a consistent national policy is a potential barrier to trade for any electricity-producing enterprise in Canada wishing to expand sales with U.S. utilities that do not have access to cross-border transmission lines. 


\section{CONCLUSION}

Electric enterprises in certain regions of southern Canada and northern Mexico enjoy natural advantages (such as less costly energy forms) in producing electric power for international trade relative to enterprises in adjoining regions of the United States. Similarly, electric enterprises on portions of the southern and northern borders of the United States enjoy advantages over counterpart Mexican and Canadian enterprises in producing electricity for import. Assuming similar institutions and policies in Canada, the United States, and Mexico, these comparative advantages should determine the level and direction of electricity trade among the three countries.

However, differences in policies and institutions in the three countries may distort the natural advantages enjoyed by enterprises in exporting electricity, thereby affecting trade or even reversing the direction of its flow. In this paper, we examined six such institutions and/or policies.

First, the organizations of the electric power industries in the three countries are very different. Decisionmaking in the U.S. electric power sector is very decentralized with more than 3,000 utilities of various ownership forms and under the regulatory jurisdiction of local, state and federal authorities. The Mexican power sector, on the other hand, is highly centralized. The Canadian industry lies between these two extremes. The economic regulation of electric power mirrors these extremes in organization, leading to different practices in recovering capital costs.

Second, changing regulatory attitudes in the three countries toward demand-side management (DSM) could also affect trade. To the extent that electric utilities reduce peak demand and conserve energy through DSM activities, the less need there may be for imported interruptible and firm power.

Third, differences in the real cost of inputs used to produce electricity are masked by differences in economic policies toward taxation and subsidies in the three countries. Differences in real cost, of course, should be the basis for determining relative advantage in producing electricity and serve as the basis for trade. Policies toward taxing energy inputs and subsidizing capital costs directly impact the selection of generating types by electric utilities. For example, high taxes on fossil fuels change the attractiveness of generating types to high capital cost-low operating cost generating stations. Capital subsidies have a similar effect.

Fourth, concerns about the harmful environmental effects of generating electricity from fossil fuels and hydropower will continue to shape the national and regional policies of governments in North America. To the extent that these policies diverge in the three countries--or evolve at different paces--the greater the chance that financial cost-justified trade flows will be distorted.

Fifth, the structures of the U.S., Mexican, and Canadian electric power industries are changing rapidly and differently. For electricity trade, these changes are significant both during the period of evolution and at the time that the structural adjustments are completed. Provisions of the Energy Policy Act of 1992 in the United States will lead to 
drastic changes in the structure of the electric power industry over the next decade and beyond. After structural adjustments are completed, the industry is expected to be more competitive in the power production portion, while remaining regulated in the transmission and distribution phases. Also, there will be open access to existing transmission facilities. Because uncertainty breeds caution, this may lead some utilities to shy away from constructing transmission lines both in the United States and across borders during the evolutionary process.

Over the longer term, opportunities for electricity trade may be enhanced. Under provisions of the North American Free Trade Agreement, the Mexican government will allow investment in Mexico's power sector for independent power production, cogeneration, and self-generation. The impact of this on trade would be two-fold. First, to the extent that the Mexican economy grows and opens up opportunities for power sales by IPPs, opportunities for cross-border trade would occur. However, to the extent that differences in environmental legislation persist between the countries in North America, there may be an impact on international electricity trade.

Sixth, there are differences in transmission access in the three countries, posing a potential barrier to expanded trade. The Energy Policy Act in the United States will help to open the existing transmission system to wheeling by third parties. However, Canada does not have a national policy or legislation for wheeling and, in Mexico, IPPs must deal with CFE for contractual arrangements to sell their power to U.S. enterprises.

Clearly, these six factors curreritly do not have the same effect on the direction and amount of electricity trade in North America. And, some factors that currently are not important may be become more significant over time because of changing conditions in the electric power industries in the three countries.

Trade in general is motivated by comparative advantage, resulting in differences in production costs among trading partners. This suggests that the most important policy and institutional differences discussed in this paper are ones that have a direct bearing on the costs of producing electricity in the three countries. For example, the subsidies provided to capital used in producing electricity are very important because electricity production is one of the most capital-intensive industries in any economy. Similarly, economic policies that directly influence the cost of other electricity inputs besides capital-e.g., taxes on energy--or the cost of imported electricity--e.g., macroeconomic policies that influence exchange rates--have a significant impact on electricity trade.

Over time, however, other factors discussed in the paper could become just as important in terms of their influence on the amount of electricity trade. Integrated resource planning processes being implemented by utilities in the United States, Canada, and Mexico are an example. In the United States, for example, electric utilities are expected to obtain one-third of additional capacity requirements from DSM by the year 2000. In border areas, DSM resources such as load management programs could be more cost-effective than imported electricity. Another potentially important influence on electricity trade over time is transmission access. To the extent that economic growth and development progresses along border areas, transmission access could become a major obstacle to trade if countries do not allow free access to transmission capacity. 


\section{REFERENICES}

Averyt, W.F. and Laver, G., 1990, "Canadian Electricity Exports, Capital Cost, and US Trade Policy," Canadian Public Policy, Vol 16, No 2, pp 145-155.

Bee, J. 1990, "Exports: The First Key to Lower Price," Asent, Vol 9 No 1, 8-9.

British Columbia Hydro, 1991, An Overview of Short Term Electricity Trade, Report Number FCH-91-04210 Vancouver, British Columbia Canada.

Cohen, S.D. et al., 1990, A Survey of State PUC Activities to Incorporate Environmental Externalities into Electric Utility Planning and Regulation, National Association of Regulatory Utility Commissioners, Washington, D.C., May.

Crowe, M.A., 1989, "Energy Trade Under the Canada-U.S. Free Trade Agreement," Northern Hydrocarbon Development in the Nineties: A Global Perspective, Carleton University, Ottawa.

Department of Energy, Mines and Resources, 1988, Le Livre-echange et l'enerie, ETDE/ CA-MS-22-105-1988, Ottawa, Ont., Canada.

Department of Energy, Mines and Resources, 1992, Electric Power in Canada 1991, ETDE/CA-MS-22-105-1988, Ottawa, Ont., Canada.

Lee, Henry, Norman Foster, and Edward Parson, 1988, Canadian Electricity Imports: An Assessment of the National Security, Economic, and Environmental Implications, Harvard University, John F. Kennedy School of Government, Cambridge, MA, Paper P-88-06, April.

Herman, L.L., 1990, Monopoly, Competition and the Free Trade Agreement: The Canadian/US Viewpoint," Energy Law '90: Changing Energy Market - The Legal Consequences, London, Graham and Totman.

Hill, Lawrence J., 1988, Public Power in the U. S. Electric Utility Industry: Regulatory Issues and Comparative Financial Indicators across Ownership Types, Oak Ridge National Laboratory, Oak Ridge, Tennessee, ORNLTM-10497, January.

Hill, Lawrence J., Eric Hirst, and Martin Schweitzer, 1991, Integrating Demand-Side Management Programs into the Resource Plans of U.S. Electric Utilities, Oak Ridge National Laboratory, Oak Ridge, Tennessee, ORNL/CON-311, January (also published by the Electric Power Research Institute, Palo Alto, California, EPRI TR-100255, December 1991 (with E. Hirst and M. Schweitzer)).

Jean-Thomas, 1989, "Reglementaion des priz de l'electricite a l'exportation apr l'one" L'Actualite Economique, Vol 61, No 1, pp 71-85.

Lee, H., 1990, "Electricity Trade: A Northeastern Perceptive," Energy and Electrical Conference Proceedings, CERI-91-01737 CONF-9006340. 
Masse, M., 1988, Energy and the Free-Trade Agreement, Energy, Mines and Resources, Canada, Ottawa Ontario, Canada.

McDogall, John M., 1991, "The Canada-U.S. Free Trade Agreement and Canada's Energy Trade," Canadian Public Policy, Vol 17, No 1, pp 1-13.

McGee D.T., 1987, Free Trade and Energy Pricing, Southam Energy Group, Toronto, Ontario.

McRae,R.N., 1991, "Canadian Energy Developments Under the Free Trade Agreement," Energy Policy, Vol 19, No 5, pp 473-479.

Montforte, Raul, 1992, "Organization of the Electric Power Sector in Mexico," Utilities Policy, 2(2), April.

National Energy Board, 1992, Inter-Utility Trade Review: Inter-Utility Cooperation, Ottawa Canada.

National Energy Board, 1992, Inter-Utility Trade Review: Transmission Access and Wheeling, Ottawa Canada.

Ryan, J., 1991, "The effects of the Free Trade Agreement on Canada's Energy Resources," Canadian Geographer, Vol 35, No. 1, pp 70-82.

Tomic, S., 1988, "The Canada-US Free Trade Agreement and Energy," Ontario Energy Network, Vol 8, No 4, PP 6-7, 11.

U.S. Department of Energy, Energy Information Administration, 1992, U.S. Electricity Trade with Canada and Mexico, DOE/EIA-0553, Washington D.C.

U.S. Department of Energy, and Secretaria de Energia, Minas e Industria Paraestatal, 1991, United States/ Mexico Electricity Trade Study, DOE/EI- 0020P, Washington D.C..

U.S. General Accounting Office, 1989, Canadian Power Imports: Update on Electricity Imports in the Northeast, Washington, DC, GAO/RCED-89-51, March. 


\section{INTERNAL DISTRIBUTION}

1. K.R. Bälew

2. E.L. Blaylock

3. M.A. Brown

4. J.B. Cannon

5. T.R. Curlee

6. S. Damewood

7. S.B. Floyd

8. S.W. Hadley

9-59. L.W. Hill
60.
E. Hillsman
61.
J.O. Kalb
62.
C.G. Rizy
63. T. J. Wilbanks
64. R.B. Shelton
65. ORNL Patent Office
66. Central Research Library
67. Document Reference Section
68-70. Laboratory Records
71. Laboratory Records - Record Copy

\section{EXTERNAL DISTRIBUTION}

72. Douglas Bohi, Resources for the Future, 1616 P. Street, N.W. Washington, DC 20036

73. Thomas Drabek, Professor, Department of Sociology, University of Denver, Denver, CO 80208-0209

73. C.D. MacCrackerı, President, Calmac Manufacturing Corporation, 101 West Sheffield Avenue, P.O. Box 710, Englewood, New Jersey 07631

74-99. Russ Profozick, Office of Policy, DOE, PO-51, Forrestal Bldg., 1000 Independence, Washington, DC 20585

100. Jacqueline Shrago, Director, Office of Technology Transfer, 405 Kirkland Hall, Vanderbilt University, Nashville, Tennessee 37240

101. George Sowers, Senior Vice President, Law Companies Group, Inc. 114 Townpark Drive, Suite 250, ennesaw, GA 30144-5599

102-103. OSTI, Department of Energy, P.O. Box 62, Oak Ridge, Tennessee 37831

104. Office of Assistant Manager, Energy Resource and Development, U.S. Department of Energy, Oak Ridge Operations, P.O. Box 2001, Oak Ridge, Tennessee 37831 


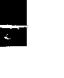

